\title{
Berberine inhibits the proliferation of human nasopharyngeal carcinoma cells via an Epstein-Barr virus nuclear antigen 1-dependent mechanism
}

\author{
CHAO WANG $^{1}$, HUAN WANG ${ }^{1}$, YAQIAN ZHANG ${ }^{1}$, WEI GUO ${ }^{2}$, CONG LONG $^{1}$, \\ JINGCHAO WANG ${ }^{1}$, LIMEI LIU ${ }^{3}$ and XIAOPING SUN ${ }^{1}$
}

\author{
${ }^{1}$ State Key Laboratory of Virology, Department of Pathogen Biology, School of Basic Medical Sciences, and \\ ${ }^{2}$ Department of Pathology and Physiology, School of Basic Medical Sciences, Wuhan University, Wuhan, Hubei 430071; \\ ${ }^{3}$ Corneal Disease Department of Weifang Eye Hospital, Weifang, Shandong 261041, P.R. China
}

Received October 3,2016; Accepted November 22, 2016

DOI: 10.3892/or.2017.5489

\begin{abstract}
Nasopharyngeal carcinoma (NPC) is a malignancy derived from the epithelial cells of the nasopharynx cavity, and is closely associated with Epstein-Barr virus (EBV) infection. In addition to NPC, EBV causes various human malignancies, such as gastric cancer, hematological tumors and lymphoepithelioma-like carcinomas. Epstein-Barr nuclear antigen 1 (EBNA1) encoded by EBV is indispensable for replication, partition, transcription and maintenance of viral genomes. Berberine, a naturally occurring isoquinoline alkaloid, shows anti-inflammatory, anticholinergic, antioxidative, and anticancer activities. In the present study, the antitumor effect of berberine was studied. Cell Counting Kit-8 (CCK-8) assays were performed to demonstrate whether the proliferation of EBV-positive NPC cells was inhibited by berberine. Flow cytometric results revealed that berberine induced cell cycle arrest and apoptosis. Quantitative-PCR and western blotting results indicated that berberine decreased the expression of EBNA1 at both the mRNA and protein levels in the EBV-positive NPC cells. The function of EBNA1 promoter Qp which is to drive EBNA1 transcription in type II latent infection was strongly suppressed by berberine. Overexpression of EBNA1 attenuated this inhibitory effect. Berberine also suppressed the activity of signal transducer and activator of transcription 3 which is a new therapeutic target in a series of malignancies, including NPC. Viral titer experiments demonstrated that berberine decreased the production of virions in HONE1 and HK1-EBV cells. In a mouse xenograft model of NPC induced by HONE1 cells,
\end{abstract}

Correspondence to: Professor Xiaoping Sun, State Key Laboratory of Virology, Department of Pathogen Biology, School of Basic Medical Sciences, Wuhan University, 185 Eastlake Road, Wuhan, Hubei 430071, P.R. China

E-mail:xsun6@whu.edu.cn

Key words: Epstein-Barr virus nuclear antigen 1, nasopharyngeal carcinoma, berberine berberine significantly inhibited tumor formation. Altogether, these results indicate that berberine decreases the expression of EBNA1 and exhibits an antitumor effect against NPC both in vitro and in vivo.

\section{Introduction}

The Epstein-Barr virus (EBV) is a common $\gamma$-herpesvirus with a high prevalence in adults worldwide (1). EBV infection is considered a high risk factor and is responsible for more than $1 \%$ of all human cancers (2). EBV infection is associated with various human proliferative diseases involving mostly epithelial or lymphoid cells, including nasopharyngeal carcinoma (NPC), gastric and lymphoepithelioma-like carcinomas (3-5). NPC occurs in the epithelium of the throat and nose and can be classified as two broad subtypes, i.e. keratinized (differentiated epithelial) and non-keratinized (undifferentiated epithelial) cells (6). NPC is prevalent in areas such as southern China, Southeast Asia, Alaska and native populations of Canada (7). EBV exhibits a type II latency mechanism in NPC patients (8-10). Type II latency infection is characterized by the expression of viral Epstein-Barr nuclear antigen 1 (EBNA1), latent membrane proteins (LMP1, LMP2A and LMP2B), and several EBV non-coding RNAs $(11,12)$. The expression of special viral antigens in NPC associated with EBV make this disease an attractive target for the therapy of NPC (9).

EBNA1 is the only viral protein expressed in all three forms of latent EBV infections (13). As an important regulator of EBV latency, EBNA1 has many functions influencing the EBV genome and host cells. For example, EBNA1 plays an essential role in the maintenance and replication of the EBV genome via sequence-specific binding to the viral origin of replication (oriP) (14). EBNA1 has been shown to modulate several cellular signaling pathways to regulate cell growth and transformation, such as nuclear factor- $\kappa \mathrm{B}(\mathrm{NF}-\kappa \mathrm{B})$, transforming growth factor- $\beta$ (TGF- $\beta$ ), and signal transducer and activator of transcription (STAT) (15-17). EBNA1 also decreases the accumulation of p53 in EBV-infected epithelial cells, leading to disruption of the antitumor functions $(18,19)$. In NPC cell type II infection, EBNA1 transcription is mediated 
by the Q promoter (Qp) (20,21). Previous studies have shown that Janus kinase (JAK)-STAT activates Qp-driven EBNA1 expression (22). Moreover, signal transducer and activator of transcription 3 (STAT3) is likely to be the biologically relevant STAT for EBNA1Qp and LMP1 L1-TR promoter regulation (23). Aberrant activation of STAT3 may be a necessary event for EBV-associated malignancies (24). In addition, increasing evidence has demonstrated that EBNA1 may be essential for the proliferation of tumor cells $(25,26)$. Collectively, EBNA1 has become an attractive target for therapeutic strategies.

Berberine is a natural compound belonging to the alkaloids, which is present in the rhizome, roots and stem bark of a number of medicinal plants such as Cortidis rhizome (Huanglian), Coptis chinensis (Chinese goldthread), Scutellaria caicalensis (Baikal Skullcap) and Berberine vulgaris (barberry) $(27,28)$. Berberine is found to have multiple pharmacological functions such as anti-diarrheal, anti-hypertensive, anti-microbial and anti-inflammatory effects (29-32). A previous study showed the potential cancer chemopreventive effect of berberine (33). Moreover, berberine has been reported to inhibit the growth of various types of cancer, such as NPC, non-small lung cancer, primary effusion lymphoma, and breast and liver cancer (34). Berberine was found to inhibit the proliferation of human breast cancer cells (MCF-7) through the downregulation of the expression of various tumor-related proteins including HER2, Bcl-2, COX-2 and EGFR, and the upregulation of p21 and IFN- $\alpha$ expression (35-38). A previous study showed that berberine induced mitochondrial apoptosis in EBV-transformed B cells through the upregulation of XAF1 and GADD $45 \alpha$ expression by MAPK and functional p53 (39). Various findings demonstrated that berberine induces the apoptosis of NPC cells through the downregulation of the activity of STAT3 (40).

Our laboratory previously demonstrated that heat shock protein 90 (Hsp90) inhibitors blocked outgrowth of EBV-infected malignant cells through an EBNA1-dependent mechanism in vitro and in vivo (41). Recently, we found that triptolide inhibited the proliferation of EBV-positive B lymphocytes via the inhibition of LMP1 (42). Moreover, our laboratory demonstrated that triptolide, a diterpenoid triepoxide purified from the roots of Chinese herb Tripterygium wilfordii, showed antitumor activity against Kaposi's sarcoma-associated herpesvirus (KSHV)-related primary effusion lymphoma through a KSHV latency-associated nuclear antigen 1-dependent mechanism (43). KSHV and EBV, members of the $\gamma$-herpesvirus subfamily, are very similar. Furthermore, in addition to inhibiting the human telomerase reverse transcriptase (hTERT) transcription and protein expression, triptolide decreased the stability of hTERT in KSHV-positive BCBL-1 and BC-3 cells (44).

In the present study, we demonstrated that berberine effectively inhibited cell proliferation and induced cycle arrest and apoptosis of EBV-positive NPC cells. Berberine decreased EBNA1 transcription by inhibiting the activation of EBNA1 promoter Qp. Berberine inhibited the expression of p-STAT3 and overexpression of EBNA1 attenuated the inhibitory effect of berberine. In addition, the production of virions were decreased by berberine. Moreover, our in vivo results revealed that tumor growth of EBV-positive NPC in non-obese diabetic/severe-combined immunodeficient (NOD/SCID) mice was effectively inhibited by a non-toxic dose $(27,45)$ of berberine. These findings may provide insights into the underlying mechanism involved in the inhibition of NPC cell proliferation by berberine.

\section{Materials and methods}

Cell lines and reagents. EBV-positive NPC cell lines HONE1 and HK1-EBV were kindly provided by Professor Sai Wah Tsao (The University of Hong Kong, Hong Kong, China). HeLa cells were obtained from Professor Hui Li (Wuhan University, Wuhan, China). The EBV-negative HK2 cells were kindly provided by Professor Ling Zheng (Wuhan University).

HONE1 and HK1-EBV cells were maintained in RPMI-1640 medium containing 10\% fetal bovine serum (FBS; Gibco-BRL, Gaithersburg, MD, USA) and G418 (400 ng/ml). HeLa cells were cultured in Dulbecco's modified Eagle's medium (DMEM) with 10\% FBS. HK2 cells were cultured in DME/F-12 containing 10\% FBS and hEGF (Sigma-Aldrich, Shanghai, China). All cell lines were cultured at $37^{\circ} \mathrm{C}$ with a humidified atmosphere of $5 \% \mathrm{CO}_{2}$. Berberine chloride, cycloheximide (CHX) (both from Sigma-Aldrich, Shanghai, China), acyclovir (ACV; Selleck Chemicals, Shanghai, China), and 12-O-tetradecanoylphorbol-13-acetate (TPA; Sigma-Aldrich) were dissolved in dimethyl sulfoxide (DMSO). Sodium butyrate (SB; Sigma-Aldrich) was dissolved in phosphate-buffered saline (PBS).

Plasmids. Plasmid pSG5-EBNA1 was constructed by ligating the EcoRI-XbaI fragment, which contains the EBNA1 sequence, into the pSG5 vector (YouBio, Shanghai, China). Plasmid pGL3.0-basic was purchased from Promega (Madison, WI, USA). PRL-TK, a plasmid expressing Renilla luciferase, was kindly provided by Professor Deyin Guo (Wuhan University). The sequence of $\mathrm{Qp}$ was amplified from the HONE1-strain EBV genome sequence. The primers used in the present study were as follows: Qp forward, 5'-TCAGATCT TATAACGCAGGTCCTG-3' and reverse, 5'-CGCAAGCTTT GTAAGGATAGCATG-3' (YouBio). The amplified sequence was digested with $B g l \mathrm{II}$ and HindIII (NEB, Ipswich, MA, USA). All plasmids were purified through columns (Axygen Scientific Inc., Union City, CA, USA) as described by the manufacturer and confirmed by DNA sequencing.

Cell viability assay. The viability of the cells was determined by the Cell Counting Kit-8 (CCK-8) assay (Dojindo Laboratories, Kumamoto, Japan). Briefly, HONE1 and HK1-EBV cells were placed into 96-well plates with DMEM at a density of $1 \times 10^{4}$ cells $/ 100 \mu \mathrm{l}$. All cells were treated with controls (DMSO; $0.006 \%, \mathrm{vol} / \mathrm{vol}$ ) and increasing concentrations of berberine for 24 and $48 \mathrm{~h}$. Tetrazolium substrates were added into each well (10 $\mu \mathrm{l} /$ well) after different treatments. The plates were incubated at $37^{\circ} \mathrm{C}$ for $1 \mathrm{~h}$. The optical density (OD) was assessed at $450 \mathrm{~nm}$ with an ELx800 microimmunoanalyser (BioTek Instruments, Inc., Winooski, VT, USA).

Flow cytometric analysis. Apoptosis was quantified using an Annexin V-FITC/propidium iodide (PI) apoptosis detection 
kit (MultiSciences, Shanghai, China). Briefly, HONE1 and HK1-EBV cells were placed in 6-well plates and treated with the vehicle control (DMSO; $0.006 \%$, vol/vol) or berberine (50 or $100 \mu \mathrm{M}$ ) for $24 \mathrm{~h}$. Cells were harvested, washed and re-suspended in $500 \mu \mathrm{l}$ of binding buffer. Then, $5 \mu \mathrm{l}$ of Annexin V-FITC and $10 \mu \mathrm{l}$ of PI were added before being analyzed by a Beckman Coulter system (EPICS Altra II; Beckman Coulter, Fullerton, CA,USA).

Cell transfection. For transfection, all cells (HONE1, HK1-EBV and HeLa) were transiently transfected using X-tremeGENE HP DNA transfection reagent (Roche, Basel, Switzerland). At $4 \mathrm{~h}$ post-transfection, cells were treated with the control (DMSO; $0.006 \%$, vol/vol) or berberine for $44 \mathrm{~h}$ before harvesting. $\mathrm{CHX}(50 \mu \mathrm{g} / \mathrm{ml})$ was used in experiments as described in the following sections.

Dual luciferase reporter assay. In brief, HeLa cells were cultured in 48 -well plates $\left(1 \times 10^{5}\right.$ cells/well $)$ before transfection. After $24 \mathrm{~h}$, pGL3.0-Qp (100 ng/well) and pRL-TK ( $5 \mathrm{ng} /$ well) were co-transfected into the HeLa cells. Then, the cells were treated with the vehicle control (DMSO; $0.006 \%$, $\mathrm{vol} / \mathrm{vol}$ ) or berberine ( 25 and $50 \mu \mathrm{M}$, respectively) for $24 \mathrm{~h}$, at $4 \mathrm{~h}$ post-transfection. Subsequently, the medium was removed and cells were rinsed twice. Total proteins were harvested in $1 \mathrm{X}$ lysis buffer (100 $\mu \mathrm{l} /$ well). Luciferase activity was assessed by the GLO-MAX 20/20 system (both from Promega) following the manufacturer's instructions. Renilla luciferase was used to normalize the firefly luciferase activity.

Quantitative-PCR. The total RNA was extracted using TRIzol reagent (Invitrogen, Grand Island, NY, USA) according to the manufacturer's instructions. First-strand cDNA was synthesized from the RNA using a reverse transcription kit (Takara, Tokyo, Japan) with random primers. The expression of LMP1 and EBNA1 mRNAs was quantified by CFX96 real-time PCR detection system using a SYBR Premix Ex Taq ${ }^{\mathrm{TM}}$ kit (Takara). The relative amounts of LMP1 and EBNA1 mRNAs were normalized to the housekeeping gene GAPDH. The primers were as follows: LMP1 forward, 5'-CTATTCCTTTGCTCTC ATGC-3' and reverse, 5'-TGAGCAGGAGGGTGATCATC-3'; EBNA1 forward, 5'-GGTCGTGGACGTGGAGAAAA-3' and reverse, 5'-GGTGGAGACCCGGATGATG-3'; GAPDH forward, 5'-ACATCGCTCAGACACCATG-3' and reverse, 5'-TGTAGTTGAGGTCAATGAAGGG-3' (YouBio). The quantitative-PCR conditions were as follows: a 30-sec denaturation at $95^{\circ} \mathrm{C}$, followed by 40 cycles of $10 \mathrm{sec}$ at $95^{\circ} \mathrm{C}, 10 \mathrm{sec}$ at $60^{\circ} \mathrm{C}$, and $20 \mathrm{sec}$ at $72^{\circ} \mathrm{C}$. The specificity of the reaction was controlled by melting curve analysis $\left(65-95^{\circ} \mathrm{C}, 0.5^{\circ} \mathrm{C} / \mathrm{sec}\right)$.

Western blotting. Cells treated under different conditions were harvested in RIPA buffer (Beyotime Institute of Biotechnology, Shanghai, China) supplemented with $0.5 \mathrm{mM}$ phenylmethylsufonyl fluoride (PMSF) and $0.5 \%$ cocktail protease inhibitor (Roche) using a micro-scraper. After being sonicated for $15 \mathrm{sec}$, whole cell extracts were obtained by centrifugation at $12,000 \mathrm{x}$ g for $15 \mathrm{~min}$. The supernatants were transferred to new tubes, and the protein concentration was determined by the bicinchoninic acid method using bovine serum albumin as a standard. Equal amounts of proteins were mixed with $5 \mathrm{X}$ loading buffer [250 $\mathrm{nM}$ Tris- $\mathrm{HCl}(\mathrm{pH} 6.8)$, $0.5 \%$ BPB, $10 \%$ SDS, $50 \%$ glycerol, $5 \% \beta$-mercaptoethanol]. The proteins were subjected to $10 \%$ SDS-polyacrylamide gel electrophoresis (SDS-PAGE). The gels were run at $110 \mathrm{~V}$, and then, the proteins were transferred onto a polyvinylidene difluoride (PVDF) membrane (Bio-Rad Laboratories, Inc., Hercules, CA, USA). The membrane was blocked with 5\% skim milk in Tris-buffered saline and Tween-20 (TBST) for $1 \mathrm{~h}$ at room temperature, followed by incubation with the primary antibody overnight at $4^{\circ} \mathrm{C}$. After $3 \times 15$ min washes with TBST, the membrane was incubated with the appropriate secondary antibodies for $1 \mathrm{~h}$.

The primary antibodies used were as follows: GAPDH (cat. no. 10494-1-AP, 1:10,000; Proteintech, Wuhan, China), EBNA1 (cat. no. sc81581, 1:200; Santa Cruz Biotechnology, Inc., Santa Cruz, CA, USA), LMP1 (1:4,000; Abcam, Cambridge, UK), BZLF1 (1:500; Dako, Glostrup, Denmark), caspase-3 (cat. no. 9668, 1:1,000), cleaved caspase-3 (cat. no. 9664, 1:1,000), STAT3 (cat. no. 9139, 1:1,000), phospho-STAT3 (cat. no. 4113, 1:1,000, Tyr705), Mcl-1 (cat. no. 14765, 1:1,000) (all from Cell Signaling Technology Inc., Danvers, MA, USA). Secondary antibodies were horseradish peroxidase-conjugated secondary anti-mouse $\mathrm{IgG}$ (cat. no. 7076, 1:10,000), anti-rabbit IgG (cat. no. 7074, 1:10,000) (both from Cell Signaling Technology Inc.). Immunoreactivity was detected using the ECL system (Bio-Rad Laboratories). Band gray values were assessed by ImageJ software (National Institutes of Health, Bethesda, MD, USA).

EBV copy number analysis. HONE1 and HK1-EBV cells were induced to lytic replication phase by TPA $(40 \mathrm{ng} / \mathrm{ml})$ and $\mathrm{SB}(3 \mathrm{mM})$. After $3 \mathrm{~h}$, cells were cultured in the absence or presence of berberine for $48 \mathrm{~h}$. EBV virion-associated DNA was collected and amplified. The supernatants of HONE1 and HK1-EBV cells were harvested and filtered with a $0.45 \mu \mathrm{l}$ filter. Each supernatant was incubated with $2 \mu \mathrm{l}$ DNase I and 10X DNase I buffer (10 mM Tris- $\mathrm{mCl}, 0.5 \mathrm{mM} \mathrm{CaCl}_{2}$, $\left.2.5 \mathrm{mM} \mathrm{MgCl}_{2}\right)$ at $37^{\circ} \mathrm{C}$. After $60 \mathrm{~min}$, EDTA $(2 \mathrm{mM}$, $20 \mu \mathrm{l}, \mathrm{pH} 8.0)$ was added to inhibit the activity of DNase I. All the samples were treated with proteinase $\mathrm{K}(0.1 \mathrm{mg} / \mathrm{ml})$ [sample:proteinase $\mathrm{K}=1: 1(\mathrm{vol} / \mathrm{vol})$ ] for $1 \mathrm{~h}$ at $50^{\circ} \mathrm{C}$. The reactions were stopped at $75^{\circ} \mathrm{C}$ after $20 \mathrm{~min}$ by inhibiting the activity of proteinase K (46). Subsequently, each sample and strand was examined for the sequence of EBNA1 by quantitative-PCR assay using a SYBR-Green PCR kit (cat no. RR420A; Takara Bio). Each quantitative-PCR reaction mixture included $2 \mu 1$ viral DNA from the prepared sample, $2 \mu \mathrm{l}$ specific primers $(0.2 \mu \mathrm{M}), 12.5 \mu \mathrm{l} 2 \mathrm{X}$ SYBR Premix Ex Taq, $0.4 \mu 1$ ROX reference dye or Dyell and PCR-grade water for a final volume of $25 \mu \mathrm{l}$. The primers were as follows: EBNA1 forward, 5'-GGTCGTGGACGTGGAGAAAA-3' and reverse, 5'-GGTGGAGACCCGGATGATG-3' (YouBio). The quantitative-PCR conditions were: a 5-sec denaturation at $95^{\circ} \mathrm{C}$, a 20 -sec annealing at $60^{\circ} \mathrm{C}$, a 2 -sec extension of primers at $72^{\circ} \mathrm{C}$ for 45 cycles. Melting curve analysis was performed from $65-95^{\circ} \mathrm{C}$ (with $0.1^{\circ} \mathrm{C} / \mathrm{sec}$ ).

In vivo tumor studies. All experimental procedures and protocols were approved by the Medical Ethics Committee of Wuhan University. The NOD/SCID mice were purchased 
and maintained in the Animal Experiment Center of Wuhan University, Animal Biosafety Level-III Laboratory.

Eight-week-old female NOD/SCID mice were subcutaneously inoculated into flanks with $1 \times 10^{7} \mathrm{HONE} 1$ cells suspended in $100 \mu \mathrm{l}$ of PBS. Seven days later, the mice (five mice/group) were treated with intraperitoneal injection of DMSO $(0.006 \%)$ or berberine $(10 \mathrm{mg} / \mathrm{kg}$, three times a week). Mice were sacrificed after three weeks by cervical dislocation. Tumor size was assessed, and then the tumors were fixed in $10 \%$ neutral buffered formalin. Immunohistochemical analysis and hematoxylin and eosin (H\&E) staining were performed according to the method described in a previous study (47).

Immunohistochemistry. Tumor samples were formalin-fixed and paraffin-embedded and cut into sections of 4- $\mu \mathrm{m}$ thickness. The sections were dewaxed in xylene, rehydrated in ethanol, washed in PBS, and then stained with H\&E. After staining, sections were dehydrated through a series of increasing concentrations of ethanol and xylene, and rehydrated in distilled water. After antigen retrieval in a sodium citrate buffer in a microwave oven, the endogenous peroxidase activity was blocked using $0.6 \% \mathrm{H}_{2} \mathrm{O}_{2}$ for $30 \mathrm{~min}$. Sections were incubated overnight at $4^{\circ} \mathrm{C}$ with a primary antibody EBNA1 (cat. no. ab8329, 1:1,000; Abcam). After washing in PBS twice, the sample sections underwent detection using the anti-mouse-specific HRP/AEC Detection IHC kit (ab127055; Abcam) according to the manufacturer's instructions.

Statistical analysis. All results were normalized to the control and are presented as the mean \pm standard deviation (mean $\pm \mathrm{SD}$ ) of at least three independent experiments. The statistical significance of the difference was evaluated by Student's t-test using GraphPad Prism (GraphPad Software, La Jolla, CA, USA). Significance was assigned at $\mathrm{p}<0.05$.

\section{Results}

Berberine inhibits the viability of EBV-positive NPC cells. To determine whether berberine (Fig. 1A) affects the cell viability of EBV-positive NPC cells, HONE1 and HK1-EBV cells were treated with a vehicle control $(0.006 \%$ DMSO) or a series of increasing concentrations of berberine $(25,50$, 100 and $200 \mu \mathrm{M}$ ) for 24 and $48 \mathrm{~h}$, respectively. Cell viability was determined by CCK- 8 assays. As shown in Fig. 1B, berberine inhibited the cell viability of HONE1 cells in a dose- and time-dependent manner. The viability of HONE1 cells was decreased from $\sim 10$ to $90 \%$ after berberine treatment for 24 and $48 \mathrm{~h}$. The $50 \%$ inhibitory concentration $\left(\mathrm{IC}_{50}\right)$ for HONE1 cells was 101.3 and $56.7 \mu \mathrm{M}$ with berberine treatment at 24 and $48 \mathrm{~h}$, respectively. Similar results were also found in the HK1-EBV cells treated with a series of increasing concentrations of berberine. The viability of HK1-EBV cells was decreased from 15 to $78 \%$ after 24 and $48 \mathrm{~h}$ of berberine treatment. The $\mathrm{IC}_{50}$ values were calculated and were 124.5 and $43.1 \mu \mathrm{M}$ at 24 and $48 \mathrm{~h}$, respectively, in the HK1-EBV cells treated with berberine (Fig. 1C). To further evaluate the effects of berberine in the EBV-negative cell line, HK2 cells were treated with the vehicle control $(0.006 \%$ DMSO) or berberine for 24 and $48 \mathrm{~h}$. As shown in Fig. 1D, treatment with a series of increasing concentrations of berberine showed a slight inhibition in the proliferation of HK2 cells at 24 and $48 \mathrm{~h}$. These results suggest that berberine inhibits the cell viability of EBV-positive NPC cells efficiently, but not significantly in HK2 cells.

Berberine induces cell cycle arrest and apoptosis in EBV-positive NPC cells. To examine whether berberine induces cell cycle arrest and apoptosis, HONE1 and HK1-EBV cells were treated with the vehicle control $(0.006 \%$ DMSO) or berberine (50 and $100 \mu \mathrm{M})$ for $24 \mathrm{~h}$. Cells were collected and stained with Annexin V-FITC/PI, followed by analyses with flow cytometry. The cell cycle analysis revealed that berberine-treated HONE1 cells underwent a G2 arrest; the percentage of G2 phase cells was $1.41 \%$ in the control group, and $16.2 \%$ in the berberine-treated group (Fig. 2A). Treatment of HK1-EBV cells with berberine resulted in G1 phase arrest; the percentage of G1 phase cells was 50.9\% in the control $(0.006 \%$ DMSO) and $56.9 \%$ in the berberine-treated group $(50 \mu \mathrm{M})$ (Fig. 2A). In addition, compared to the control group (0.006\% DMSO), berberine (50 or $100 \mu \mathrm{M})$ induced cell apoptosis in the HONE1 and HK1-EBV cells (Fig. 2B). The results suggest that berberine induced cell cycle arrest and apoptosis in the EBV-positive HONE1 and HK1-EBV cells.

Berberine decreases EBNAl expression in EBV-positive NPC cells. To determine whether berberine alters the expression of EBNA1 in EBV-positive NPC cell lines, HONE1 and HK1-EBV cells were treated with the vehicle control $(0.006 \%$ DMSO) or berberine ( 25 or $50 \mu \mathrm{M})$ for $48 \mathrm{~h}$. Whole-cell extracts were harvested and subjected to western blotting. As shown in Fig. 3A, the expression levels of EBNA1 in the HONE1 cells were decreased to 36.8 and $6.7 \%$, with berberine treatment at 25 and $50 \mu \mathrm{M}$, respectively, when compared to the control group. HK1-EBV cells were also treated with the same concentrations of berberine. When compared to the control group, the expression levels of EBNA1 were not significantly affected in the $25 \mu \mathrm{M}$ berberine-treated group, but downregulated to $32.4 \%$ in the $50 \mu \mathrm{M}$ berberine-treated group. However, the expression level of another EBV protein, LMP1, was not decreased by berberine in both the HONE1 and HK1-EBV cells. Furthermore, compared to the control group, the expression levels of cleaved-caspase-3 in the HONE1 and HK1-EBV cells were increased while the levels of caspase- 3 exhibited no obvious changes with berberine treatment. The different response of the HONE1 and HK1-EBV cells to berberine is possibly due to the different sensitivity of the cell lines to this drug.

In addition, quantitative PCR analysis was used to detect whether berberine affects LMP1 at the mRNA level. HONE1 and HK1-EBV cells were treated with the vehicle control ( $0.006 \%$ DMSO) or berberine $(25$ or $50 \mu \mathrm{M})$ for $24 \mathrm{~h}$, respectively. The total RNAs were collected and subjected to quantitative-PCR. The relative expression of LMP1 was detected by comparison to the GAPDH gene. As shown in Fig. 3B, the mRNA levels of LMP1 in the HONE1 and HK1-EBV cells were not decreased by berberine.

Berberine treatment in a previous study was not observed to affect the viability of EBV-negative HeLa cells (48). Therefore, HeLa cells were used to determine whether berberine specifically decreases the expression of EBNA1 in the present study. In order to determine whether berberine specifically decreases 
A<smiles>COc1ccc2cc3[n+](cc2c1OC)CCc1cc2c(cc1-3)OCO2</smiles>

C

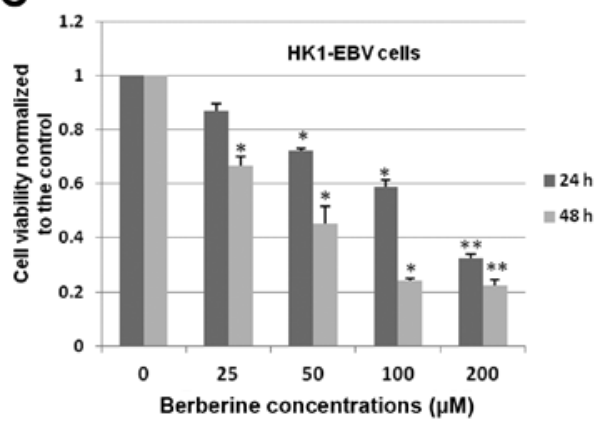

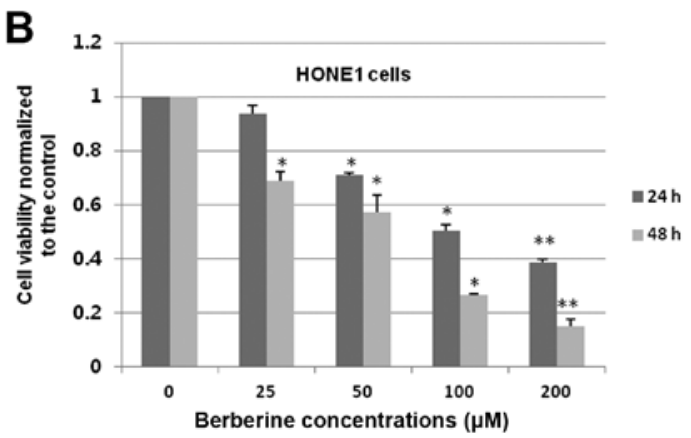

D

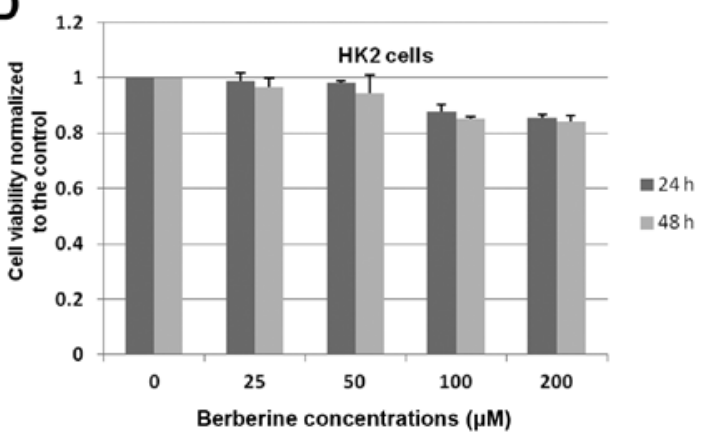

Figure 1. Berberine inhibits the proliferation of EBV-positive NPC cells. (A) Molecular structure of berberine. (B) HONE1, (C) HK1-EBV and (D) HK2 cells were treated with the vehicle control ( $0.006 \%$ DMSO only) or a series of concentrations of $25,50,100$ and $200 \mu \mathrm{M}$ of berberine for 24 or $48 \mathrm{~h}$, respectively. The cell proliferation assay was carried out using a CCK-8 assay kit as described in Materials and methods. The mean values of at least three independent experiments are shown; ${ }^{*} \mathrm{p}<0.05 ;{ }^{* *} \mathrm{p}<0.01$, compared with the vehicle control (0.006\% DMSO). EBV, Epstein-Barr virus; NPC, nasopharyngeal carcinoma; DMSO, dimethyl sulfoxide.

A

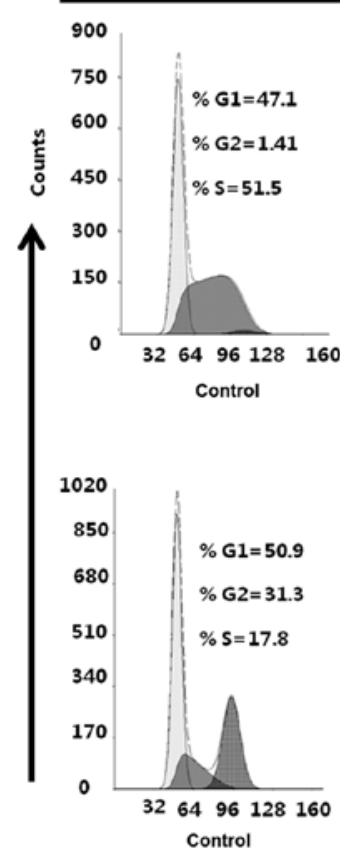

$24 \mathrm{~h}$

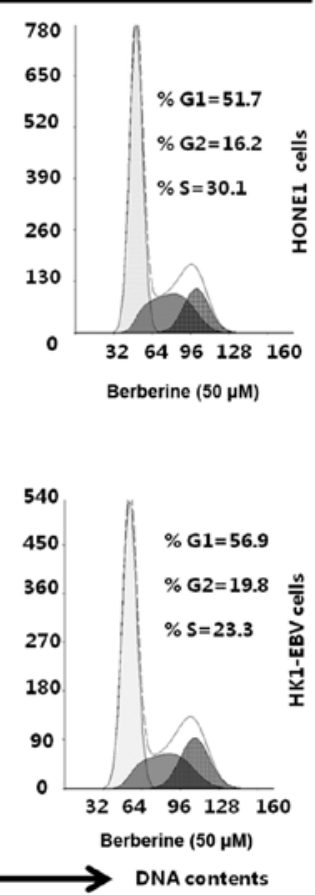

B

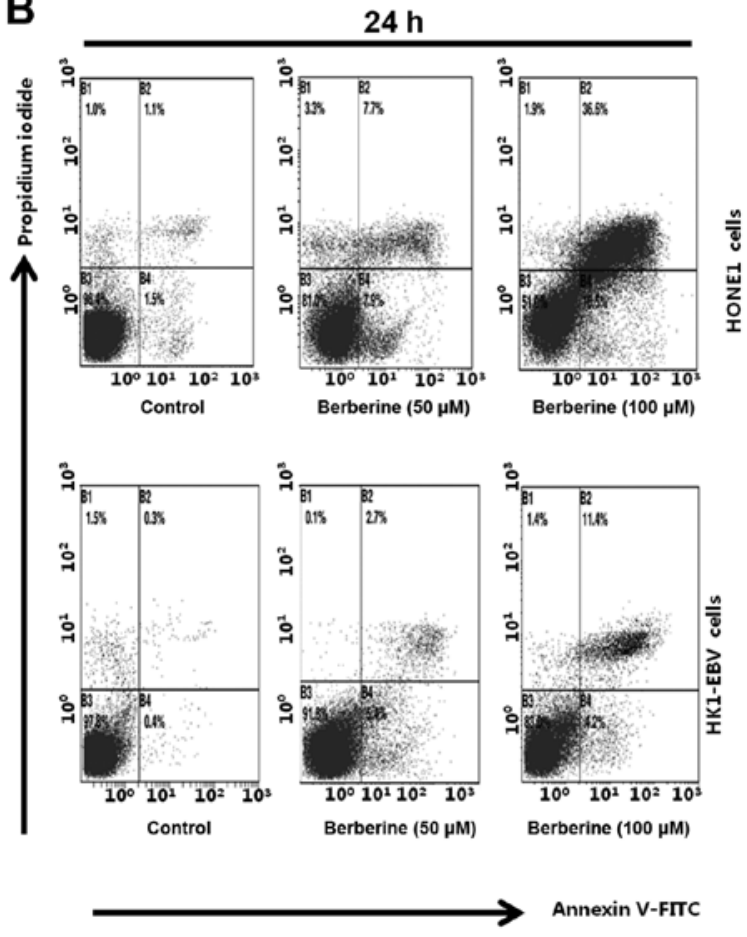

Figure 2. Berberine induces cell cycle arrest and apoptosis in the EBV-positive NPC cells. (A) The effect of berberine on the cell cycle. HONE1 or HK1-EBV cells were treated with the vehicle control ( $0.006 \%$ DMSO) or indicated concentrations of berberine for $24 \mathrm{~h}$, respectively. The distribution of the cell cycle was determined by flow cytometry. (B) The effect of berberine on apoptosis. HONE1 or HK1-EBV cells were treated with the vehicle control (0.006\% DMSO) or indicated concentrations of berberine for $24 \mathrm{~h}$. Apoptotic cells were determined by flow cytometry. EBV, Epstein-Barr virus; NPC, nasopharyngeal carcinoma; DMSO, dimethyl sulfoxide.

the expression of EBNA1, p-SG5 and pSG5-EBNA1 were transiently transfected into HeLa cells for $4 \mathrm{~h}$, followed by treatment with or without berberine. As shown in Fig. 3C, when compared to the control group, the expression levels of EBNA1 were not 
A
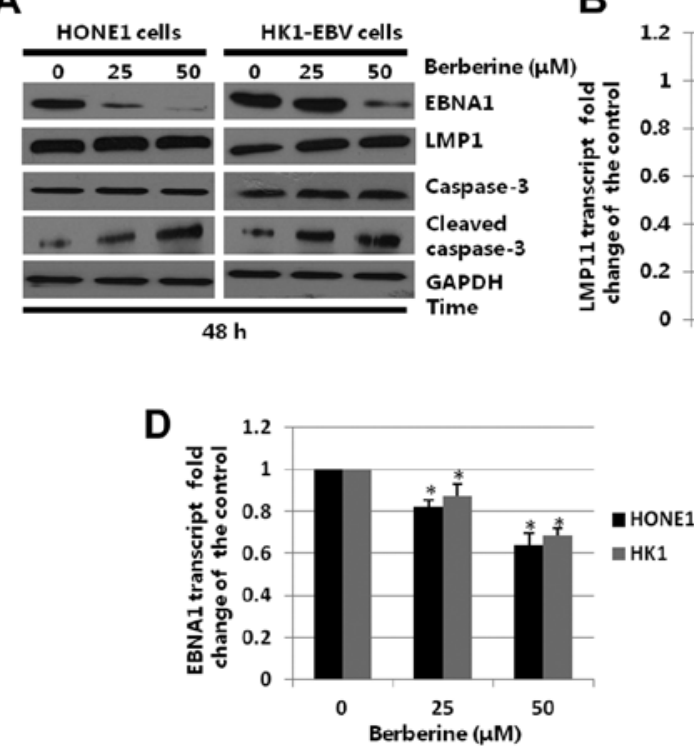

$\mathbf{F}$

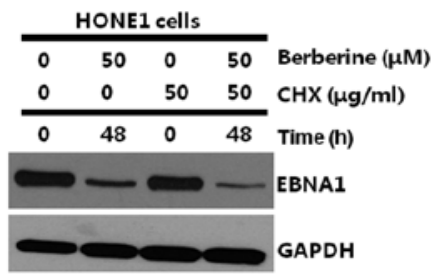

B

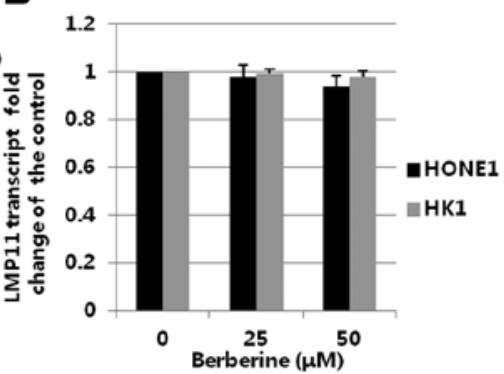

C

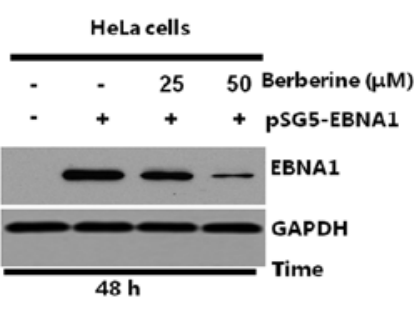

E

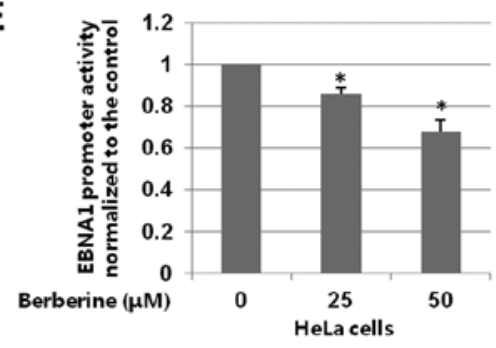

G

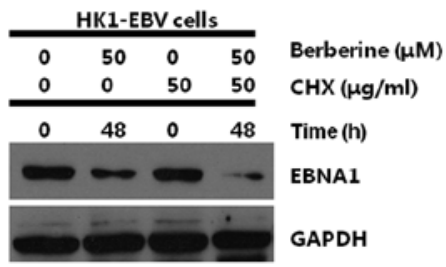

Figure 3. Effect of berberine on the transcription, expression and half-life of the EBNA1 protein in HONE1 or HK1-EBV cells. (A) HONE1 or HK1-EBV cells were placed in 6-well plates and treated with the vehicle control $(0.006 \%$ DMSO) or berberine $(25$ or $50 \mu \mathrm{M})$ for $48 \mathrm{~h}$. Whole-cell extracts were prepared and western blotting was performed to analyze the expression of EBNA1, caspase-3, cleaved caspase-3 and GAPDH. (B) HONE1 and HK1-EBV cells were treated with the vehicle control $(0.006 \%$ DMSO) or berberine $(25$ or $50 \mu \mathrm{M})$ for $24 \mathrm{~h}$. The mRNA levels of LMP1 were detected by quantitative-PCR. The level of LMP1 transcript in cells treated with the vehicle control was set as 1. (C) HeLa cells were transfected with pSG5 or pSG5-EBNA1 as indicated, followed by a 44-h berberine $(25$ or $50 \mu \mathrm{M})$ treatment beginning at $4 \mathrm{~h}$ after transfection. Whole-cell extracts were prepared and western blotting was performed to analyze the expression of EBNA1 and GAPDH. (D) HONE1 or HK1-EBV cells were treated with the vehicle control (0.006\% DMSO) or berberine (25 or $50 \mu \mathrm{M})$ for $48 \mathrm{~h}$. The mRNA levels of EBNA1 were determined by quantitative-PCR. The level of EBNA1 transcript in cells treated with the vehicle control was set as 1 ; ${ }^{*} \mathrm{p}<0.05$, compared with vehicle control (0.006\% DMSO). (E) HeLa cells were co-transfected with pGL3.0-Qp and pRL-TK, followed by a 24 h treatment with the vehicle control $(0.006 \%$ DMSO) or berberine $(25$ or $50 \mu \mathrm{M})$ beginning at $4 \mathrm{~h}$ post-transfection. Cell lysates were harvested and the activity of the promoter was determined by a dual-luciferase reporter assay; "p<0.05, compared with the vehicle control (0.006\% DMSO). (F) HONE1 and (G) HK1-EBV cells were treated with the vehicle $(0.006 \%$ DMSO) or berberine $(50 \mu \mathrm{M})$ for $48 \mathrm{~h}$ in the presence or absence of $\mathrm{CHX}(50 \mu \mathrm{g} / \mathrm{ml})$ added to the medium $12 \mathrm{~h}$ before cell harvesting. Whole-cell extracts were harvested and subjected to western blotting. EBNA1, Epstein-Barr nuclear antigen 1; EBV, Epstein-Barr virus; DMSO, dimethyl sulfoxide; LMP1, latent membrane protein 1; CHX, cycloheximide.

significantly affected in the $25 \mu \mathrm{M}$ berberine-treated group, but downregulated to $32.5 \%$ in the $50 \mu \mathrm{M}$ berberine-treated group.

To further determine whether the decreased expression of EBNA1 was due to possible alterations at the transcriptional levels, HONE1 and HK1-EBV cells were treated with the vehicle control $(0.006 \%$ DMSO) or berberine $(25$ or $50 \mu \mathrm{M})$. After $24 \mathrm{~h}$, the total RNAs were harvested and subjected to quantitative-PCR. As shown in Fig. 3D, berberine decreased EBNA1 mRNA levels to $81.23 \%$ in the $25 \mu \mathrm{M}$ and $63.17 \%$ in the $50 \mu \mathrm{M}$ berberine-treated groups, respectively, when compared with the vehicle control (0.006\% DMSO) group in the HONE1 cells. In the HK1-EBV cells, the EBNA1 mRNA levels were decreased to $85.39 \%(\mathrm{p}<0.05)$ in the $25 \mu \mathrm{M}$ and $65.73 \%$ $(\mathrm{p}<0.05)$ in the $50 \mu \mathrm{M}$ berberine-treated groups, respectively, when compared with the vehicle control (0.006\% DMSO) group. These results demonstrated that berberine inhibited the mRNA levels of EBNA1 in HONE1 and HK1-EBV cells.

Berberine inhibits the activity of EBNA1 $Q p$. EBNA1 transcription is initiated from Qp in EBV-associated NPC cells.
According to our previous studies $(42,44)$, the promoters of latent membrane protein 1 (LMP1) and human telomerase reverse transcriptase (hTERT) were studied in HeLa and 293T cells. To determine whether berberine inhibited the activity of EBNA1 promoter, pGL3.0 vector control or pGL3.0-Qp was co-transfected with plasmid pRL-TK into HeLa cells. The HeLa cells were treated with the control (0.006\% DMSO) or berberine ( 25 or $50 \mu \mathrm{M})$ for $24 \mathrm{~h}$, at $4 \mathrm{~h}$ post-transfection. The whole protein was harvested and the luciferase activity was assessed using the GLO-MAX 20/20 system (Promega). Compared to the control group, the activity of Qp was decreased to $83.4 \%(\mathrm{p}<0.05)$ and $62.7 \%(\mathrm{p}<0.05)$ in the 25 and $50 \mu \mathrm{M}$ berberine-treated groups, respectively (Fig. 3E). The results suggest that the transcriptional activity of EBNA1 was decreased by berberine in the HeLa cell line.

Berberine decreases the half-life of EBNA1. To determine whether berberine decreases the protein half-life of EBNA1, HONE1 and HK1-EBV cells were treated with the vehicle control or berberine, in the presence of $\mathrm{CHX}$. As shown in 
A

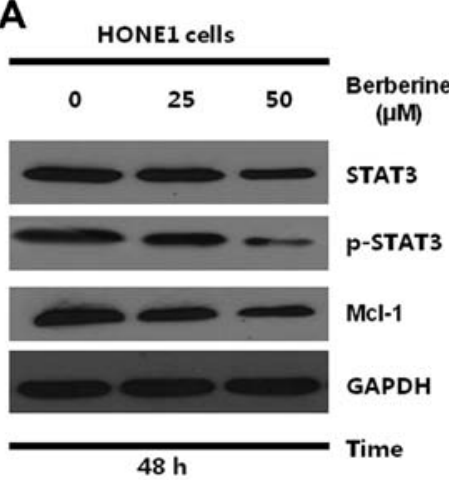

B

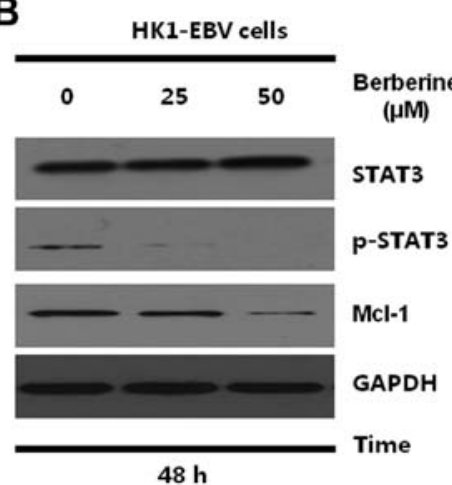

Figure 4. Berberine inhibits the STAT3 signaling pathway in NPC cells. (A) HONE1 and (B) HK1-EBV cells were treated with the vehicle control (0.006\% DMSO) or berberine ( 25 or $50 \mu \mathrm{M})$ for $48 \mathrm{~h}$, respectively. Whole-cells extracts were collected and western blotting was performed to analyze the expression of STAT3, p-STAT3 and GAPDH, respectively. STAT3, signal transducer and activator of transcription 3; NPC, nasopharyngeal carcinoma; DMSO, dimethyl sulfoxide.

Fig. 3F and $\mathrm{G}$, berberine decreased the half-life of the EBNA1 protein in the CHX-treated HONE1 and HK1-EBV cells when compared to the vehicle control. The results suggest that berberine decreases the half-life of EBNA1.

Berberine downregulates STAT3 signaling in the NPC cells. The Qp promoter that drives the expression of EBNA1 in EBV-associated tumors is regulated by the JAK-STAT signaling pathway $(22,23)$. STAT3 is essential for the activation of Qp and raises the possibility that aberrant activation of STAT3 may be an essential factor in EBV-associated diseases (22). Since STAT3 represents a potential target for treatment of EBV-associated tumors, it may be beneficial to determine whether the activity of STAT3 is affected by berberine. Therefore, HONE1 and HK1-EBV cells were treated with the vehicle control $(0.006 \%$ DMSO) or berberine $(25$ or $50 \mu \mathrm{M})$. After $48 \mathrm{~h}$, the total proteins were collected and subjected to western blotting. As shown in Fig. $4 \mathrm{~A}$ and B, the expression of STAT3 and p-STAT3 were detected in the HONE1 and HK1-EBV cells. Berberine suppressed the expression of p-STAT3 effectively in the HONE1 and HK1-EBV cells. Furthermore, the present study demonstrated that the downregulation of p-STAT3 was associated with the suppressed expression of Mcl-1, which is a downstream survival protein of STAT3. These results suggest that downregulation of EBNA1 by berberine is possibly related to the inhibition of the STAT3 signaling pathway in NPC cells.

Overexpression of EBNAI attenuates the effect of berberine. To determine whether the berberine-induced decrease in cell viability (Fig. 1B and $C$ ) is mainly caused by the inhibited expression of EBNA1, pSG5-EBNA1 or the vehicle control (pSG5) were transfected into HONE1 and HK1-EBV cells. The cells were treated with the vehicle control $(0.006 \%$ DMSO) or berberine $(50 \mu \mathrm{M})$ at $4 \mathrm{~h}$ post-transfection. After $44 \mathrm{~h}$, the total proteins were harvested and subjected to western blotting. As shown in Fig. 5A and B, the expression levels of EBNA1 were increased by $301.3 \%$ in the HONE1 cells, and $368.1 \%$ in the HK1-EBV cells, respectively, by transient transfection.

Cell viability was detected after 24 and $48 \mathrm{~h}$. As shown in Fig. 5C and D, the cell viability of both HONE1 and HK1-EBV cells was significantly decreased by berberine.
Following the overexpression of EBNA1, the cell viability was increased by $19.8 \%(\mathrm{p}<0.05)$ in the HONE1 cells and $22.4 \%(\mathrm{p}<0.05)$ in the HK1-EBV cells after $24 \mathrm{~h}$, respectively, when compared with the control group (berberine-treated control group). After $48 \mathrm{~h}$, compared to the control group (berberine-treated control group), the cell viability was increased by $24.5 \%(\mathrm{p}<0.05)$ in the HONE1 cells and $27.6 \%$ $(\mathrm{p}<0.05)$ in the HK1-EBV cells. Overexpression of EBNA1 increased cell viability and decreased the inhibitory effect of berberine. These results suggest that berberine inhibits the proliferation of EBV-positive HONE1 and HK1-EBV cells possibly through a mechanism related to the decreased expression of EBNA1.

Berberine decreases latent and lytic replication of $E B V$ in $E B V$-positive NPC cells. To determine whether berberine inhibits lytic replication of EBV, HONE1 and HK1-EBV cells uninduced or induced by TPA and SB were treated with the indicated concentrations of berberine for $48 \mathrm{~h}$. Aciclovir (ACV) was used as a positive control, efficiently decreasing virion production of EBV. After induction, the culture media of HONE1 and HK1-EBV cells were prepared after $48 \mathrm{~h}$ incubation and processed for the detection of the EBV EBNA1 fragment. Quantitative-PCR and western blotting were used to detect the effect of berberine on lytic replication of EBV. As shown in Fig. 6A and B, berberine decreased viral genome copies in both uninduced and induced HONE1 and HK1-EBV cells. As expected, $\mathrm{ACV}$, which was used as a positive control, significantly decreased the viral genome copies in the induced HONE1 and HK1-EBV cells. The results indicated that virions were decreased by berberine in a dose-dependent manner. The aforementioned cell lysates were harvested. Western blotting was used to analyze the effect of berberine on the expression of EBV transcriptional activator BZLF1 encoded by the EBV immediate-early (IE) gene in the HONE1 and HK1-EBV cells. As shown in Fig. 6C and D, the expression levels of the EBV transcriptional activator BZLF1 in the HONE1 and HK1-EBV cells were decreased by berberine in both the uninduced and induced HONE1 and HK1-EBV cells. The results suggest that berberine decreased latent and lytic replication of EBV in the HONE1 and HK1-EBV cells. 
A

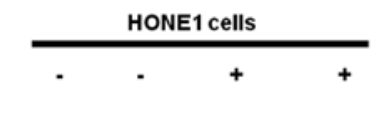

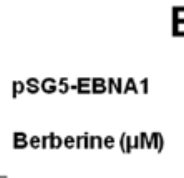

EBNA1

GAPDH
B

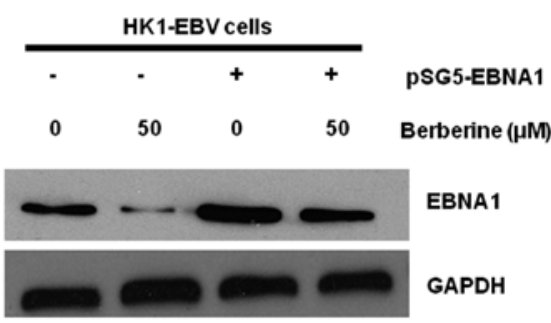

C

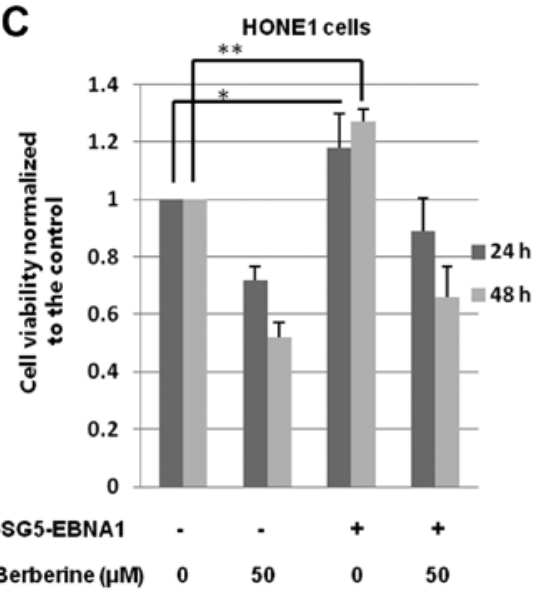

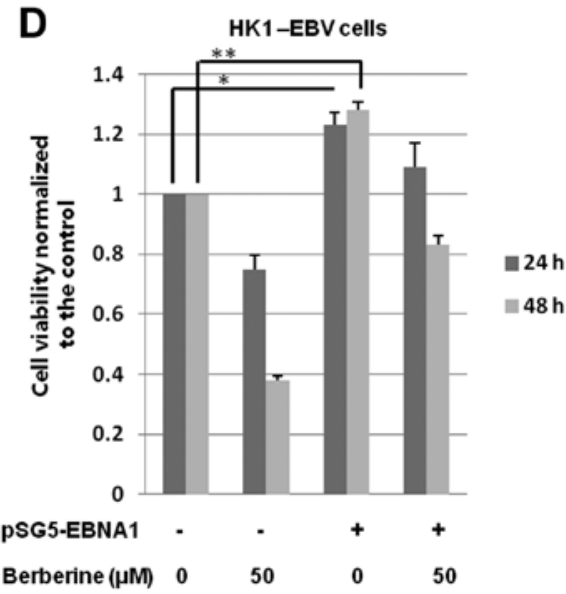

Figure 5. Overexpression of EBNA1 attenuates the inhibitory effect of berberine on the cell viability of EBV-positive NPC cells. (A) HONE1 and (B) HK1-EBV cells were transiently transfected with empty vector pSG5 ('-' means pSG5) or pSG5-EBNA1 ('+' means pSG5-EBNA1), and then, treated with berberine $(50 \mu \mathrm{M})$ at $4 \mathrm{~h}$ post-transfection. After $44 \mathrm{~h}$, total proteins were harvested and western blotting was performed to determine the EBNA1 and GAPDH expression levels. The cell viability of (C) HONE1 and (D) HK1-EBV cells was determined by CCK- 8 assay after 24 or $48 \mathrm{~h}$, respectively; ${ }^{*} p<0.05$, ${ }^{* *} \mathrm{p}<0.01$ compared with the control group. EBNA1, Epstein-Barr nuclear antigen 1; EBV, Epstein-Barr virus; NPC, nasopharyngeal carcinoma.

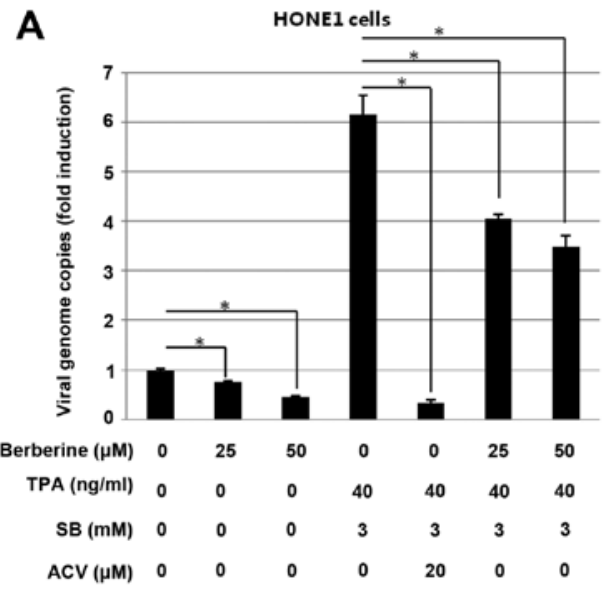

C

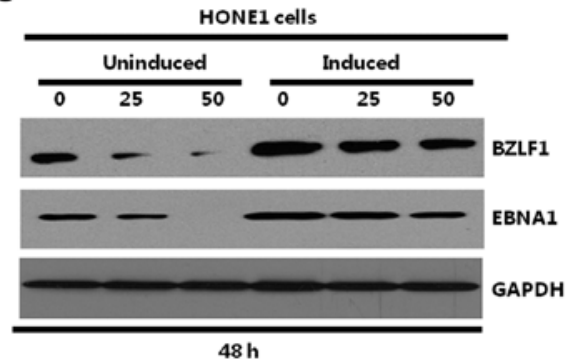

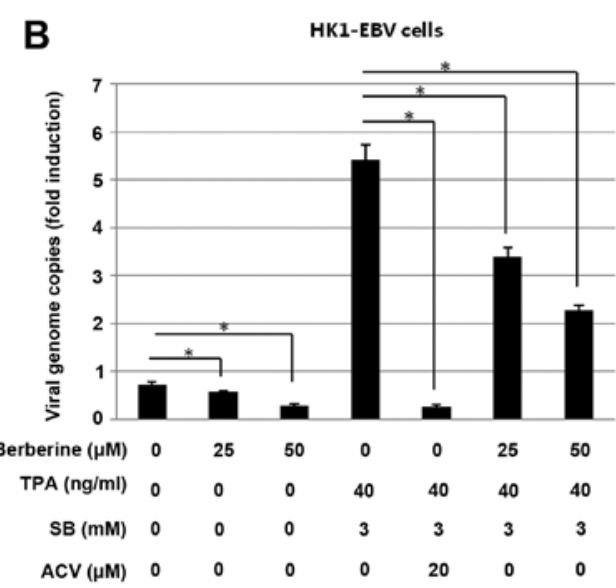

D

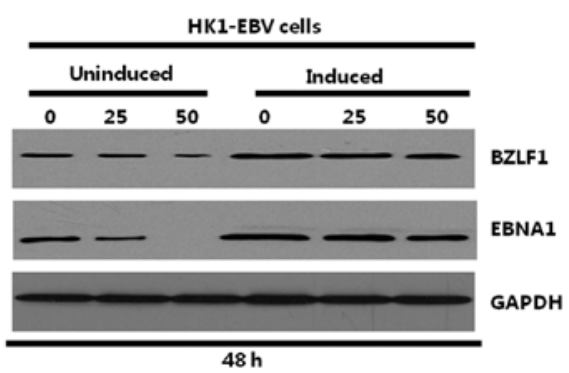

Figure 6. Berberine inhibits EBV virion production in EBV-positive NPC cells. (A) HONE1 and (B) HK1-EBV cells were treated with TPA (40 ng/ml) and SB $(3 \mathrm{mM})$ for EBV induction. After $3 \mathrm{~h}$, uninduced and induced HONE1 and HK1-EBV cells were treated with the vehicle control (0.006\% DMSO) or indicated concentrations of berberine for $48 \mathrm{~h}$. Subsequently, the culture medium was harvested for quantitative-PCR analysis with EBNA1 primers. Each sample was normalized to the amount of the GAPDH gene; ${ }^{p} \mathrm{p}<0.05$, compared with the control group. The aforementioned (C) HONE1 and (D) HK1-EBV cell lysates were harvested and subjected to western blotting. EBV, Epstein-Barr virus; NPC, nasopharyngeal carcinoma; TPA, 12-O-tetradecanoylphorbol-13-acetate; SB, sodium butyrate; DMSO, dimethyl sulfoxide. 
A

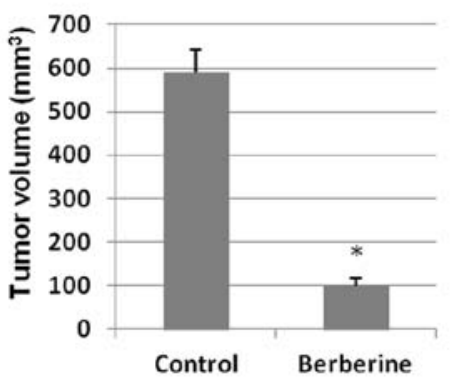

D

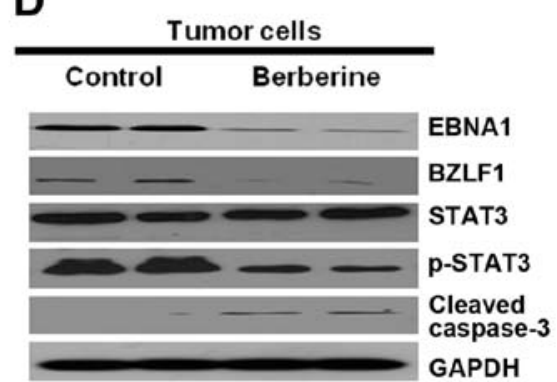

F

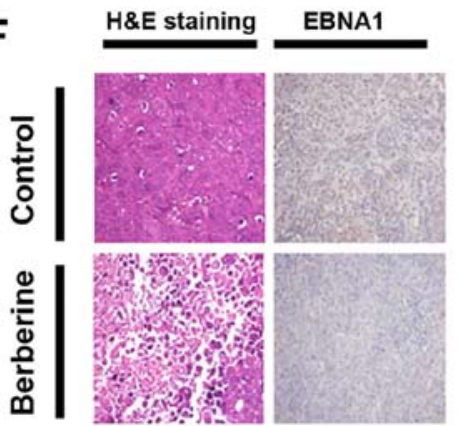

B

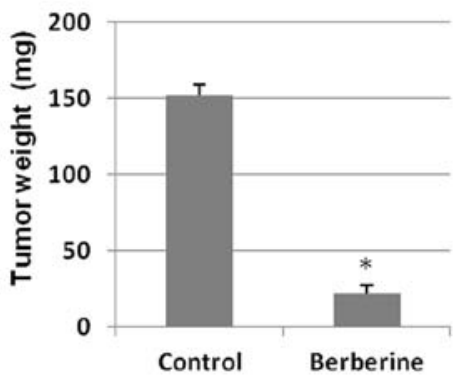

C

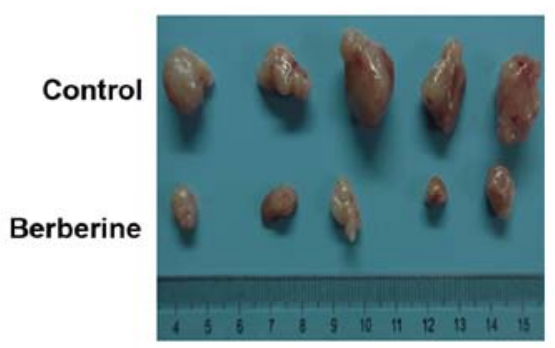

E

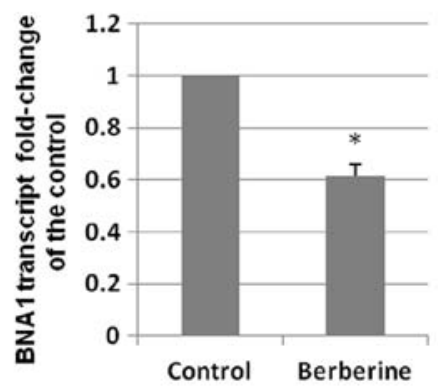

G

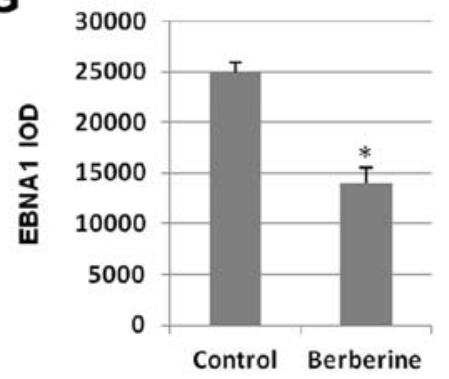

Figure 7. Treatment of NOD/SCID mice with berberine inhibits the growth of NPC in vivo. NOD/SCID mice with hypodermic tumors were treated with DMSO or berberine $(10 \mathrm{mg} / \mathrm{kg}$, three times a week) for three weeks totally. (A) Tumor volumes and (B) tumor weights were evaluated at the end of the experiment. Whole values are expressed as the means \pm SD of five mice; * $p<0.05$, compared with the control group (DMSO only). (C) Representative images of tumors from the vehicle control (DMSO) and the berberine-treated group are shown. (D) Tumor tissues were collected and subjected to protein extraction, followed by western blotting with the indicated antibodies. Two of the three independent experiments are shown. (E) Total RNAs of tumor tissues were extracted. The EBNA1 mRNA levels in the tumor tissues were detected by quantitative-PCR. The expression of EBNA1 mRNA was normalized against GAPDH levels; ${ }^{*} \mathrm{p}<0.05$, compared with the control group (DMSO only). (F) Tumor tissues were subjected to H\&E staining. Immunohistochemical staining using anti-EBNA1 was used to detect EBV-positive cells in tumor tissues. Randomly selected micrographs are presented. (G) The EBV-positive cells from the immunohistochemical staining experiments with anti-EBNA1 were quantified and displayed; ${ }^{*} \mathrm{p}<0.05$, compared with the control group (DMSO). NPC, nasopahryngeal carcinoma; EBNA1, Epstein-Barr nuclear antigen 1; EBV, Epstein-Barr virus; IOD, integrated option density.

Berberine inhibits tumor growth in severely immunodeficient mice. Since the aforementioned results demonstrate the inhibition of NPC cell proliferation by berberine, the possible effects of berberine in vivo were investigated. To determine whether berberine inhibits the growth of the EBV-positive NPC in NOD/SCID mice, $1 \times 10^{7} \mathrm{HONE} 1$ cells were subcutaneously inoculated in the flanks of the mice. After seven days, a dose of $10 \mathrm{mg} / \mathrm{kg}$ of berberine or DMSO was administered via subcutaneous injection three times a week. After three weeks, the mice were euthanized and the volumes and weights of the tumors were assessed. The tumor volumes of the DMSO-treated group were larger than that of the berberine-treated group $\left(98.75 \pm 13\right.$ vs. $590.5 \pm 12.3 \mathrm{~mm}^{3}, \mathrm{n}=5, \mathrm{p}<0.05$; Fig. 7A). Mice treated with berberine had a significantly lower tumor weight $(22.25 \pm 7.5$ vs. $152.5 \pm 10.2 \mathrm{mg}, \mathrm{n}=5, \mathrm{p}<0.05$; Fig. $7 \mathrm{~B})$. Images of tumors in mice treated with DMSO or berberine are shown in Fig. 7C.

To determine the mechanism by which berberine inhibits tumor growth, the expression levels of EBNA1, BZLF1, p-STAT3 and cleaved caspase-3 in the tumor tissues were analyzed by western blotting. Compared to the DMSO-treated group, berberine downregulated the expression level of EBNA1 significantly and induced tumor cell apoptosis via the caspase-3 pathway. In addition, the expression of BZLF1 was decreased by berberine (Fig. 7D). Then, total RNAs were extracted from tumor tissues. The mRNA levels were analyzed by quantitative-PCR. The mRNA level of EBNA1 in the berberine-treated group was decreased to $61.3 \%$ of the control group (Fig. 7E).

Both the vehicle control (DMSO) and the berberine-treated tumor tissue groups were analyzed by H\&E staining and 
EBNA1 immunostaining (Fig. 7F). The tumor tissues of the berberine-treated group were found to have necrosis and a small amount of inflammatory cell infiltration. The number of EBNA1-positive cells in the berberine-treated mice was significantly decreased compared to the control group. As shown in Fig. 7G, the number of EBNA1-positive cells in the tumor tissues of the berberine-treated group were decreased by $40.2 \%(\mathrm{p}<0.05)$ compared to those of the DMSO-treated group. The results suggest that berberine significantly inhibits the growth of EBV-positive NPC cells in vivo.

\section{Discussion}

Nasopharyngeal carcinoma (NPC) is distinguished from other types of head and neck cancers due to its unique sensitivity to radiotherapy and chemotherapy (49). Although a number of drugs have been used as chemotherapy agents (such as cisplatin and cetuximab), a relapse rate as high as $34 \%$ still confounds clinicians (50). Therefore, novel therapeutic strategies such as molecular-targeted therapy are needed. EBNA1 has been shown to alter the cellular environment and contribute to cell survival, proliferation, immortalization and tumorigenesis, providing an attractive target for Epstein-Barr virus (EBV)-associated diseases (51). Our previous study demonstrated that Hsp90 inhibitors block outgrowth of EBV-infected malignant cells through an EBNA1-dependent mechanism (41). Thus, development of new drugs that can inhibit the activity of EBNA1 may be therapeutically useful. In the present study, we investigated the effect of berberine on EBV-positive NPC cells in vitro and in vivo. Our results suggest that berberine effectively inhibits EBV-positive NPC cell proliferation, and induces cycle arrest and apoptosis.

Berberine, an active ingredient extracted from the herb Coptidis rhizome, which has long been used as an anti-diarrheal, a stomachic, an antibiotic, and an anti-inflammatory agent in China has been reported to have anticancer properties in multiple cancer cell lines, such as breast, colon and liver cancer $(30,31,52)$. EBNA1 is reported to be an essential protein in all NPC tumors, and is the only EBV protein needed for the persistence and replication of EBV episomes (53). Our findings revealed that berberine decreased EBNA1 expression in two different EBV-positive NPC cell lines and EBV-negative HeLa cells transfected with pSG5-EBNA1 transiently-expressing EBNA1. The activity of the EBNA1 promoter in EBV latency II infection was inhibited by berberine in HeLa cells. In addition, the stability or half-life of EBNA1 was decreased by berberine. These results suggest that berberine inhibited the expression EBNA1 at both the mRNA and protein levels in HONE1 and HK1-EBV cells.

Our previous study demonstrated that triptolide suppressed the activity of LMP1 promoter ED-L1 in latency III type EBV-positive B lymphocytes (42). In NPC, EBV exhibits a type II latency program. In the present study, the mRNA level of EBNA1 was decreased by berberine. Moreover, the activity of the EBNA1 promoter Qp was inhibited by berberine, suggesting that inhibition of EBNA1 promoter activity resulted in the inhibition of EBNA1 at the transcriptional level.

Previous studies have shown that STAT3 is an attractive target for anticancer therapy (24). STAT3 is an important transcriptional factor that functions in numerous physiological processes including cancer development, inflammation, immunity and wound healing. In human breast (MDA-MB-231) and pancreatic (Panc-1) cancer cell lines, the STAT3 inhibitor suppressed the viability, survival, growth and malignant transformation, effectively (54). STAT3 also contributes to EBV and KSHV-mediated cancers by promoting cell proliferation, angiogenesis and invasion. In addition, recent evidence indicated that aberrant activation of STAT3 is essential for the tumorigenesis and progression of NPC (55). STAT3 was activated almost immediately by EBV upon infection of primary cells. EBV utilizes STAT3 to inhibit cellular self-protection functions. A previous study implicated STAT3 as a biologically relevant STAT for the activation of Qp and L1-TR promoters and raises the possibility that aberrant activation of STAT3 may be a contributing factor to EBV-associated tumorigenesis (23). Furthermore, evidence has demonstrated that aberrant activation of the STAT3 pathway is associated with tumor invasion and metastasis in various types of cancer. STAT3 is constitutively activated without any stimulus in HONE1 and HK1-EBV cells. In the present study, the expression levels of p-STAT3 and Mcl-1 (a downstream survival protein of STAT3) were significantly downregulated by berberine. Our results indicate that downregulation of the expression levels of EBNA1 in NPC may be at least partially a result from the inhibition of STAT3 activity by berberine. The mechanism in which STAT3 mediates berberine-induced inhibition of EBNA1 may be studied in the future.

In addition to LMP1, EBNA1 contributes to viral transcription and multiple effects on cellular proteins and pathways that promote cell survival and proliferation (56-58). Our laboratory recently demonstrated that overexpression of LMP1 increases the cell viability of EBV-positive B lymphocytes, B95-8 and P3HR cells (42). In the present study, we found that overexpression of EBNA1 increased the cell viability of HONE1 and HK1-EBV cells. The results demonstrated that berberine decreased the proliferation and activity of EBV-positive NPC cells partly due to the decrease in EBNA1 expression.

In addition to the latent infection of EBV, the lytic reactivation of EBV has been reported to be strongly associated with several human diseases, including NPC. Inhibition of the EBV lytic cycle has been shown to be of great benefit in the treatment of EBV-associated diseases. Consistent with the effect of berberine in decreasing the expression of EBNA1 in EBV-latent infected cells, the present study demonstrated that berberine decreased the expression of the lytic gene BZLF1 in uninduced and induced EBV-positive NPC cells. At present, the mechanism involved in the inhibition of gene expression and lytic replication of EBV by berberine is not very clear and warrants further study. Collectively, berberine induces cell cycle arrest and apoptosis, downregulates the expression of EBNA1 and suppresses lytic replication of EBV in EBV-positive NPC cells.

In addition to the inhibitory effect of berberine on EBV-positive NPC cells in vitro, we also investigated the therapeutic effect of berberine on NPC in a xenograft mouse model. Consistent with the ability of Hsp90 inhibitors to suppress tumors in NOD/SCID mice by decreasing the expression of EBNA1 (41), berberine displayed a significant effect on the inhibition of tumor growth in NOD/SCID mice induced by the injection of HONE1 cells. Moreover, berberine 
decreased the expression of EBNA1 and BZLF1 in the xenograft tumor cells.

In the present study, our results demonstrated the ability of berberine to decrease cell proliferation, induce cell cycle arrest and promote apoptosis in the EBV-positive NPC cells. The inhibitory activity of STAT3 provides evidence justifying the decrease of EBNA1 levels induced by berberine. In addition, berberine has the ability to inhibit the lytic replication of EBV-positive NPC cells. Thus, berberine may be used as a novel therapy in the treatment of EBV-associated tumors including NPC.

\section{Acknowledgements}

The present study was supported by the Initiative Research Program of Wuhan University (no. 410100020), the Advanced Talent Independent Research Program of Wuhan University (no. 410500011), and the National Natural Science Foundation of China (no. 31270205).

\section{References}

1. Martin KA, Lupey LN and Tempera I: Epstein-Barr virus oncoprotein LMP1 mediates epigenetic changes in host gene expression through PARP1. J Virol 90: 8520-8530, 2016.

2. Cui Q, Feng FT, Xu M, Liu WS, Yao YY, Xie SH, Li XZ, Ye ZL, Feng QS, Chen LZ, et al: Nasopharyngeal carcinoma risk prediction via salivary detection of host and Epstein-Barr virus genetic variants. Oncotarget, 2016.

3. Xu M, Cheung CC, Chow C, Lun SW, Cheung ST and Lo KW: Overexpression of PIN1 enhances cancer growth and aggressiveness with cyclin D1 induction in EBV-associated nasopharyngeal carcinoma. PLoS One 11: e0156833, 2016.

4. Sivachandran N, Thawe NN and Frappier L: Epstein-Barr virus nuclear antigen 1 replication and segregation functions in nasopharyngeal carcinoma cell lines. J Virol 85: 10425-10430, 2011.

5. Mansouri S, Pan Q, Blencowe BJ, Claycomb JM and Frappier L: Epstein-Barr virus EBNA1 protein regulates viral latency through effects on let-7 microRNA and dicer. J Virol 88: 11166-11177, 2014

6. Houldcroft CJ and Kellam P: Host genetics of Epstein-Barr virus infection, latency and disease. Rev Med Virol 25: 71-84, 2015.

7. Zhu DD, Zhang J, Deng W, Yip YL, Lung HL, Tsang CM, Law WT, Yang J, Lau VM, Shuen WH, et al: Significance of NF- $\kappa$ B activation in immortalization of nasopharyngeal epithelial cells. Int J Cancer 138: 1175-1185, 2016.

8. Wang FW, Wu XR, Liu WJ, Liang YJ, Huang YF, Liao YJ, Shao CK, Zong YS, Mai SJ and Xie D: The nucleotide polymorphisms within the Epstein-Barr virus $\mathrm{C}$ and $\mathrm{Q}$ promoters from nasopharyngeal carcinoma affect transcriptional activity in vitro. Eur Arch Otorhinolaryngol 269: 931-938, 2012.

9. Shen Y, Zhang S, Sun R, Wu T and Qian J: Understanding the interplay between host immunity and Epstein-Barr virus in NPC patients. Emerg Microbes Infect 4: e20, 2015.

10. Sam CK, Brooks LA, Niedobitek G, Young LS, Prasad U and Rickinson AB: Analysis of Epstein-Barr virus infection in nasopharyngeal biopsies from a group at high risk of nasopharyngeal carcinoma. Int J Cancer 53: 957-962, 1993.

11. Kelly GL, Stylianou J, Rasaiyaah J, Wei W, Thomas W, Croom-Carter D, Kohler C, Spang R, Woodman C, Kellam P, et al: Different patterns of Epstein-Barr virus latency in endemic Burkitt lymphoma (BL) lead to distinct variants within the BL-associated gene expression signature. J Virol 87: 2882-2894, 2013.

12. Kempkes B and Ling PD: EBNA2 and its coactivator EBNA-LP. Curr Top Microbiol Immunol 391: 35-59, 2015.

13. Frappier L: Contributions of Epstein-Barr nuclear antigen 1 (EBNA1) to cell immortalization and survival. Viruses 4: 1537-1547, 2012.

14. Dheekollu J, Wiedmer A, Sentana-Lledo D, Cassel J, Messick T and Lieberman PM: HCF1 and OCT2 cooperate with EBNA1 to enhance OriP-dependent transcription and episome maintenance of latent Epstein-Barr virus. J Virol 90: 5353-5367, 2016.
15. Wood VH, O'Neil JD, Wei W, Stewart SE, Dawson CW and Young LS: Epstein-Barr virus-encoded EBNA1 regulates cellular gene transcription and modulates the STAT1 and TGF $\beta$ signaling pathways. Oncogene 26: 4135-4147, 2007.

16. Valentine R, Dawson CW, Hu C, Shah KM, Owen TJ, Date KL, Maia SP, Shao J, Arrand JR, Young LS, et al: Epstein-Barr virus-encoded EBNA1 inhibits the canonical NF-kappaB pathway in carcinoma cells by inhibiting IKK phosphorylation. Mol Cancer 9: 1, 2010.

17. Tempera I, De Leo A, Kossenkov AV, Cesaroni M, Song H, Dawany N, Showe L, Lu F, Wikramasinghe P and Lieberman PM: Identification of $M E F 2 B, E B F 1$, and IL6R as direct gene targets of Epstein-Barr virus (EBV) nuclear antigen 1 critical for EBV-infected B-lymphocyte survival. J Virol 90: 345-355, 2015.

18. Holowaty MN, Sheng Y, Nguyen T, Arrowsmith C and Frappier L: Protein interaction domains of the ubiquitin-specific protease, USP7/HAUSP. J Biol Chem 278: 47753-47761, 2003.

19. Saridakis V, Sheng Y, Sarkari F, Holowaty MN, Shire K, Nguyen T, Zhang RG, Liao J, Lee W, Edwards AM, et al: Structure of the $\mathrm{p} 53$ binding domain of HAUSP/USP7 bound to Epstein-Barr nuclear antigen 1 implications for EBV-mediated immortalization. Mol Cell 18: 25-36, 2005.

20. Wang FW, Wu XR, Liu WJ, Liao YJ, Lin S, Zong YS, Zeng MS, Zeng YX, Mai SJ and Xie D: Heat shock factor 1 upregulates transcription of Epstein-Barr Virus nuclear antigen 1 by binding to a heat shock element within the BamHI-Q promoter. Virology 421: 184-191, 2011.

21. Brooks L, Yao QY, Rickinson AB and Young LS: Epstein-Barr virus latent gene transcription in nasopharyngeal carcinoma cells: Coexpression of EBNA1, LMP1, and LMP2 transcripts. J Virol 66: 2689-2697, 1992.

22. Chen H, Lee JM, Zong Y, Borowitz M, Ng MH, Ambinder RF and Hayward SD: Linkage between STAT regulation and Epstein-Barr virus gene expression in tumors. J Virol 75: 2929-2937, 2001.

23. Chen H, Lee JM, Wang Y, Huang DP, Ambinder RF and Hayward SD: The Epstein-Barr virus latency BamHI-Q promoter is positively regulated by STATs and Zta interference with JAK/STAT activation leads to loss of BamHI-Q promoter activity. Proc Natl Acad Sci USA 96: 9339-9344, 1999.

24. Yu H and Jove R: The STATs of cancer - new molecular targets come of age. Nat Rev Cancer 4: 97-105, 2004.

25. Imai S, Kuroda M, Yamashita R and Ishiura Y: Therapeutic inhibition of Epstein-Barr virus-associated tumor cell growth by dominant-negative EBNA1. Uirusu 55: 239-249, 2005 (In Chinese).

26. Coppotelli G, Mughal N, Callegari S, Sompallae R, Caja L, Luijsterburg MS, Dantuma NP, Moustakas A and Masucci MG: The Epstein-Barr virus nuclear antigen-1 reprograms transcription by mimicry of high mobility group A proteins. Nucleic Acids Res 41: 2950-2962, 2013.

27. Goto H, Kariya R, Shimamoto M, Kudo E, Taura M, Katano H and Okada S: Antitumor effect of berberine against primary effusion lymphoma via inhibition of NF- $\kappa$ B pathway. Cancer Sci 103: 775-781, 2012.

28. Lin JP, Yang JS, Lee JH, Hsieh WT and Chung JG: Berberine induces cell cycle arrest and apoptosis in human gastric carcinoma SNU-5 cell line. World J Gastroenterol 12: 21-28, 2006.

29. Peng PL, Hsieh YS, Wang CJ, Hsu JL and Chou FP: Inhibitory effect of berberine on the invasion of human lung cancer cells via decreased productions of urokinase-plasminogen activator and matrix metalloproteinase-2. Toxicol Appl Pharmacol 214: 8-15, 2006.

30. Kim JB, Yu JH, Ko E, Lee KW, Song AK, Park SY, Shin I, Han W and Noh DY: The alkaloid Berberine inhibits the growth of Anoikis-resistant MCF-7 and MDA-MB-231 breast cancer cell lines by inducing cell cycle arrest. Phytomedicine 17: 436-440, 2010.

31. Kishimoto A, Dong SF, Negishi H, Yasui N, Sun JN and Ikeda K: Effects of berberine on adipose tissues and kidney function in 3T3-L1 cells and spontaneously hypertensive rats. Nat Prod Commun 10: 1543-1546, 2015.

32. Bae YA and Cheon HG: Activating transcription factor-3 induction is involved in the anti-inflammatory action of berberine in RAW264.7 murine macrophages. Korean J Physiol Pharmacol 20: 415-424, 2016.

33. Wang J, Qi Q,Feng Z, Zhang X, Huang B, Chen A, Prestegarden L, $\mathrm{Li} X$ and Wang $\mathrm{J}$ : Berberine induces autophagy in glioblastoma by targeting the AMPK/mTOR/ULK1-pathway. Oncotarget 7: 66944-66958, 2016. 
34. Barzegar E, Fouladdel S, Movahhed TK, Atashpour S, Ghahremani MH, Ostad SN and Azizi E: Effects of berberine on proliferation, cell cycle distribution and apoptosis of human breast cancer T47D and MCF7 cell lines. Iran J Basic Med Sci 18: 334-342, 2015.

35. Liu J, He C, Zhou K, Wang J and Kang JX: Coptis extracts enhance the anticancer effect of estrogen receptor antagonists on human breast cancer cells. Biochem Biophys Res Commun 378: 174-178, 2009.

36. Abukhdeir AM, Vitolo MI, Argani P, De Marzo AM, Karakas B, Konishi H, Gustin JP, Lauring J, Garay JP, Pendleton C, et al: Tamoxifen-stimulated growth of breast cancer due to p21 loss. Proc Natl Acad Sci USA 105: 288-293, 2008.

37. Kuo CL, Chi CW and Liu TY: Modulation of apoptosis by berberine through inhibition of cyclooxygenase-2 and Mcl-1 expression in oral cancer cells. In Vivo 19: 247-252, 2005.

38. Hwang JM, Kuo HC, Tseng TH, Liu JY and Chu CY: Berberine induces apoptosis through a mitochondria/caspases pathway in human hepatoma cells. Arch Toxicol 80: 62-73, 2006.

39. Park GB, Park SH, Kim D, Kim YS, Yoon SH and Hur DY: Berberine induces mitochondrial apoptosis of EBV-transformed $B$ cells through p53-mediated regulation of XAF1 and GADD45 $\alpha$. Int J Oncol 49: 411-421, 2016.

40. Tsang CM, Cheung YC, Lui VW, Yip YL, Zhang G, Lin VW, Cheung KC, Feng $\mathrm{Y}$ and Tsao SW: Berberine suppresses tumorigenicity and growth of nasopharyngeal carcinoma cells by inhibiting STAT3 activation induced by tumor associated fibroblasts. BMC Cancer 13: 619, 2013.

41. Sun X, Barlow EA, Ma S, Hagemeier SR, Duellman SJ, Burgess RR, Tellam J, Khanna R and Kenney SC: Hsp90 inhibitors block outgrowth of EBV-infected malignant cells in vitro and in vivo through an EBNA1-dependent mechanism. Proc Natl Acad Sci USA 107: 3146-3151, 2010.

42. Zhou H, Guo W, Long C, Wang H, Wang J and Sun X: Triptolide inhibits proliferation of Epstein-Barr virus-positive $\mathrm{B}$ lymphocytes by down-regulating expression of a viral protein LMP1. Biochem Biophys Res Commun 456: 815-820, 2015.

43. Long C, Guo W, Zhou H, Wang J, Wang H and Sun X: Triptolide decreases expression of latency-associated nuclear antigen 1 and reduces viral titers in Kaposi's sarcoma-associated and herpesvirus-related primary effusion lymphoma cells. Int $\mathrm{J}$ Oncol 48: 1519-1530, 2016 .

44. Long C, Wang J, Guo W, Wang H, Wang C, Liu Y and Sun X: Triptolide inhibits transcription of hTERT through down-regulation of transcription factor specificity protein 1 in primary effusion lymphoma cells. Biochem Biophys Res Commun 469: 87-93, 2016.

45. Xu M, Xiao Y, Yin J, Hou W, Yu X, Shen L, Liu F, Wei L and Jia W: Berberine promotes glucose consumption independently of AMP-activated protein kinase activation. PLoS One 9 e103702, 2014

46. Wu CC, Fang CY, Hsu HY, Chen YJ, Chou SP, Huang SY, Cheng YJ, Lin SF, Chang Y, Tsai $\mathrm{CH}$, et al: Luteolin inhibits Epstein-Barr virus lytic reactivation by repressing the promoter activities of immediate-early genes. Antiviral Res 132: 99-110, 2016.
47. Choi ES, Nam JS, Jung JY, Cho NP and Cho SD: Modulation of specificity protein 1 by mithramycin A as a novel therapeutic strategy for cervical cancer. Sci Rep 4: 7162, 2014.

48. Saha SK and Khuda-Bukhsh AR: Berberine alters epigenetic modifications, disrupts microtubule network, and modulates HPV-18 E6-E7 oncoproteins by targeting p53 in cervical cancer cell HeLa: A mechanistic study including molecular docking. Eur J Pharmacol 744: 132-146, 2014

49. Paiar F, Di Cataldo V, Zei G, Pasquetti EM, Cecchini S, Meattini I, Mangoni M, Agresti B, Iermano C, Bonomo P, et al: Role of chemotherapy in nasopharyngeal carcinoma. Oncol Rev 6: e1, 2012.

50. Gu J, Yin L, Wu J, Zhang N, Huang T, Ding K, Cao H, Xu L and $\mathrm{He} \mathrm{X}$ : Cetuximab and cisplatin show different combination effect in nasopharyngeal carcinoma cells lines via inactivation of EGFR/AKT signaling pathway. Biochem Res Int 2016: 7016907, 2016.

51. Frappier L: Role of EBNA1 in NPC tumourigenesis. Semin Cancer Biol 22: 154-161, 2012.

52. Li CH, Wu DF, Ding H, Zhao Y, Zhou KY and Xu DF: Berberine hydrochloride impact on physiological processes and modulation of twist levels in nasopharyngeal carcinoma CNE-1 cells. Asian Pac J Cancer Prev 15: 1851-1857, 2014.

53. O'Neil JD, Owen TJ, Wood VH, Date KL, Valentine R, Chukwuma MB, Arrand JR, Dawson CW and Young LS: Epstein-Barr virus-encoded EBNA1 modulates the AP-1 transcription factor pathway in nasopharyngeal carcinoma cells and enhances angiogenesis in vitro. J Gen Virol 89: 2833-2842, 2008.

54. Aziz MH, Hafeez BB, Sand JM, Pierce DB, Aziz SW, Dreckschmidt NE and Verma AK: Protein kinase $\mathrm{C} \varepsilon$ mediates Stat3Ser727 phosphorylation, Stat3-regulated gene expression, and cell invasion in various human cancer cell lines through integration with MAPK cascade (RAF-1, MEK1/2, and ERK1/2). Oncogene 29: 3100-3109, 2010

55. Liu YP, Tan YN, Wang ZL, Zeng L, Lu ZX, Li LL, Luo W, Tang $\mathrm{M}$ and Cao Y: Phosphorylation and nuclear translocation of STAT3 regulated by the Epstein-Barr virus latent membrane protein 1 in nasopharyngeal carcinoma. Int J Mol Med 21: 153-162, 2008.

56. Kennedy G, Komano J and Sugden B: Epstein-Barr virus provides a survival factor to Burkitt's lymphomas. Proc Natl Acad Sci USA 100: 14269-14274, 2003.

57. Hong M, Murai Y, Kutsuna T, Takahashi H, Nomoto K, Cheng CM, Ishizawa S, Zhao QL, Ogawa R, Harmon BV, et al: Suppression of Epstein-Barr nuclear antigen 1 (EBNA1) by RNA interference inhibits proliferation of EBV-positive Burkitt's lymphoma cells. J Cancer Res Clin Oncol 132: 1-8, 2006.

58. Yin Q and Flemington EK: siRNAs against the Epstein Barr virus latency replication factor, EBNA1, inhibit its function and growth of EBV-dependent tumor cells. Virology 346: 385-393, 2006. 